\title{
FREQUENCY RATIO LANDSLIDE SUSCEPTIBILITY ESTIMATION IN A TROPICAL MOUNTAIN REGION
}

\author{
D.N. Javier ${ }^{1 *}$, L. Kumar ${ }^{2}$ \\ ${ }^{1}$ College of Science, University of the Philippines Baguio, Baguio City, Philippines 2600 - dnjavier@up.edu.ph \\ ${ }^{2}$ School of Environmental and Rural Science, University of New England, Armidale, New South Wales, Australia 2350 - \\ lkumar@une.edu.au
}

Commission VI, WG VI/4

KEY WORDS: Landslide database, Landslide susceptibility, Frequency ratio, GIS, Philippines

\begin{abstract}
:
In a high-rainfall, landslide-prone region in this tropical mountain region, a landslide database was constructed from high resolution satellite imagery (HRSI), local reports and field observations. The landslide data was divided into training $(80 \%)$ and validation sets (20\%). From the digital elevation model (DEM), scanned maps and HRSI, twelve landslide conditioning factors were derived and analysed in a GIS environment: elevation, slope angle, slope aspect, plan curvature, profile curvature, distance to drainage, soil type, lithology, distance to fault/lineament, land use/land cover, distance to road and normalized difference vegetation index (NDVI). Landslide susceptibility was then estimated using the frequency ratio method as applied on the training data. The detailed procedure is explained herein. The landslide model generated was then evaluated using the validation data set. Results demonstrate that the very high, high, moderate, low and very low susceptibility classes included an average of $86 \%, 7 \%, 4 \%, 3 \%$ and $1 \%$ of the training cells, and $84 \%, 7 \%, 5 \%, 3 \%$ and $1 \%$ of the validation cells, respectively. Success and prediction rates obtained were $90 \%$ and $89 \%$, respectively. The sound output has discriminated well the landslide prone areas and thus may be used in landslide hazard mitigation for local planning.
\end{abstract}

\section{INTRODUCTION}

In the Global Landslide Catalog (Kirschbaum et al., 2015), the Philippines and its Asian neighbors are considered landslide hotspots. Located in the Circum-Pacific Ring of Fire and the western North Pacific basin, the Philippines face landslides triggered by earthquakes and high rainfall from tropical cyclones. The passage of tropical cyclones and/or southwest monsoon activity coincide with the annual occurrence of rainfall-induced landslides (RIL). Most RIL occur during the months May to October. For the years 1951-2013, an annual average of 19.4 tropical cyclones cross the Philippine area of responsibility (PAR) (Cinco et al., 2016). The greatest number hit northern Luzon, making the region recognized locally and globally as among the most landslide-prone (Forbes and Broadhead, 2011; Kjekstad and Highland, 2009; Nadim et al., 2006; Petley, 2012; Yumul et al., 2011). Among the affected places is the municipality of Tublay, province of Benguet (Figure 1). Predisposing geologic features, together with high rainfall ( $\sim 3892 \mathrm{~mm}$ per year) and human activities have placed the area at high risk for landslides and related hazards (NolascoJavier et al., 2015). Among the most damaging landslide events were those during Typhoon Parma in October 2009.

With the availability of recent high-resolution satellite imagery and access to GIS and statistical software, a more detailed and current landslide susceptibility map may be generated in a process that is expeditious, straightforward, evidence-based and cost-effective (Akgun et al., 2012; Aleotti and Chowdhury, 1999; Greenbaum, 1995; Magliulo et al., 2009; Metternicht et al., 2005; Pradhan , 2010a; Van Westen et al., 2008).

This study was undertaken with the following objectives: (1) to estimate landslide susceptibility using the frequency ratio method for an area in mountainous Tublay, Benguet,
Philippines, and (2) to validate the landslide susceptibility model. The output from this work could potentially aid in decision making in the aftermath of an extreme rainfall event (e.g. provide basis for early warning), conceptualization and design of rehabilitation and mitigation measures, and environmental impact assessment, land use planning and development planning. The procedure for landslide susceptibility modelling could be adapted in other similar landslide-prone areas in the region and elsewhere.

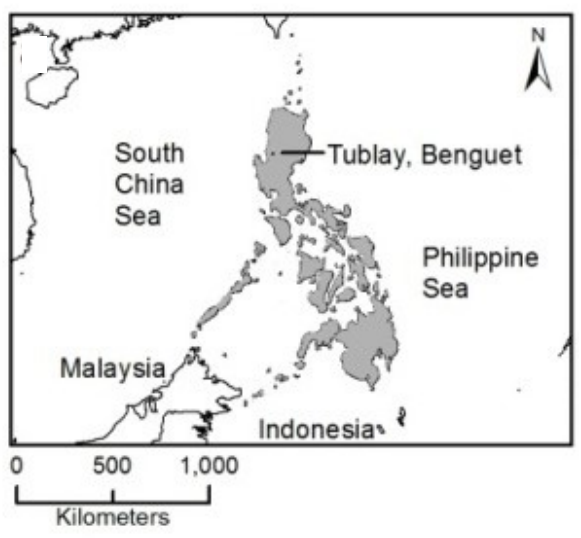

Figure 1. Location map of Tublay municipality, Benguet province in northern region of the Philippines (shaded area)

\section{DATA AND METHODS}

\subsection{Preparation of the landslide database}

The interpretation of maps, aerial photographs and satellite images, complemented with field surveys and review of historical archives are commonly used in generating a landslide 
inventory. The higher spatial and spectral resolution of HRSI and possible manipulation in a GIS environment also allow better identification and confirmation of pertinent features in the study area, in difficult terrain or even inaccessible areas (Martha et al., 2015). Since no recent aerial photographs were available for the study area, we thus acquired a cloud-free WorldView-2 (WV2) image, having multispectral and panchromatic band resolutions of $1.85 \mathrm{~m}$ and $0.46 \mathrm{~m}$ ground sample distance at nadir, respectively. The capture dates were December 2009 and April 2010. The projection was WGS 1984 UTM Zone 51N.

In satellite images, the occurrence of landslides is suggested by breaks in the forest canopy, bare soil, characteristic head and flank scarps, flow tracks, and lobate forms of deposits (Borghuis et al., 2007; Intarawichian and Dasananda , 2011; Lee and Min , 2001). Research has also confirmed the usefulness of the Normalized Difference Vegetation Index (NDVI) as an initial criterion for delineating landslides (Barlow et al., 2003; Fernández et al., 2008; Martha et al., 2010; Miller 2013). NDVI values close to 1 indicate the presence of dense green vegetation, while values below or close to zero indicate sparse or no vegetation. An NDVI thematic map was generated using ArcMap. Previous workers using WV2 applied NDVI thresholds of 0.2 (Abuzar et al., 2014) and 0.25 (Pu and Landry, 2012) to distinguish vegetated and non-vegetated areas, the latter regarded as landslide candidates. We adopted the empirically derived criterion NDVI $<0.3$ to quickly identify potential landslide areas. The threshold was deemed applicable on the basis of visual inspection of the pan-sharpened image and field survey data. The near infrared-1 and red bands with wavelengths of 770-895 nm and 630-690 nm, respectively (DigitalGlobe, 2013), were used in the equation

$\mathrm{NDVI}=(\mathrm{NIR}-\mathrm{R}) /(\mathrm{NIR}+\mathrm{R}) \quad($ Eq. 1$)$.

We also generated band ratios in ENVI 5.1 to highlight the textural features of bare ground. The ratios band $7 /$ band 2 , band $5 /$ band 3 , and band $6 /$ band 4 proved useful when displayed as RGB false color composites. Combining information from NDVI, band ratios and field data, features such as rivers, floodplains, roads, mines, quarries, fallow fields, and building areas were excluded from the landslide candidates.

The landslide polygons were then digitized onscreen. The larger landslides, i.e., those with areas of more than $900 \mathrm{~m}^{2}$, were selected as they were deemed as more damaging. The retained landslides were then randomly split into training $(80 \%)$ and validation $(20 \%)$ data. The landslide polygons were converted to a raster grid of $10 \mathrm{~m} \mathrm{x} 10 \mathrm{~m}$ grid cells.

\subsection{Extraction of landslide conditioning factors}

The chosen landslide conditioning factors were those that, based on existing literature, field experience and available data, were recognized to influence slope instability. For this study, landslide conditioning factors were extracted or generated from three major sources of information: the DEM, scanned maps, and HRSI. For this study area, a $10 \mathrm{~m}$ x $10 \mathrm{~m}$ synthetic aperture radar (SAR) DEM was obtained from the Nationwide Disaster Risk and Exposure Assessment for Mitigation (DREAM) Program of the Department of Science and Technology and the University of the Philippines Training Center for Applied Geodesy and Photogrammetry. The DEM was obtained through Radarsat-2 for the period February 2012 to September 2013. The absolute vertical accuracy LE90 is $<10 \mathrm{~m}$. Although collected post-Typhoon Parma (October 2009), the SAR DEM is regarded as suitable because most of the Parma-triggered landslides are active and have shown movement every rainy season.

The landslide conditioning factors were generated from available data sources (Table 1). The twelve selected factors are among those recognized to influence shear stresses, slope resistance to instability, subsurface flow velocity, runoff rate and water retention (Dahal et al., 2012; Jaafari et al., 2014; Manzo et al., 2013; Ozdemir and Altural, 2013; Pourghasemi et al., 2013; Pradhan, 2010b; Van Asch et al., 1999; Van Westen, 1997).

\begin{tabular}{|c|c|c|c|}
\hline $\begin{array}{l}\text { Source } \\
\text { map/ } \\
\text { images }\end{array}$ & Data type & Resolution & Source \\
\hline $\begin{array}{l}\text { Landslide } \\
\text { locations }\end{array}$ & Polygon & $2 \mathrm{~m} \times 2 \mathrm{~m}$ & $\begin{array}{ll}\text { World } & \text { View2 } \\
\text { image }\end{array}$ \\
\hline DEM & Grid & $\begin{array}{l}10 \mathrm{~m} \times 10 \\
\mathrm{~m}\end{array}$ & $\begin{array}{lr}\text { Disaster } & \text { Risk } \\
\text { Exposure and } \\
\text { Assessment for } \\
\text { Mitigation } \\
\text { (DREAM) project } \\
\end{array}$ \\
\hline $\begin{array}{l}\text { Geological } \\
\text { map }\end{array}$ & Polygon & $1: 50000$ & $\begin{array}{l}\text { Mines and } \\
\text { Geosciences } \\
\text { Bureau }\end{array}$ \\
\hline Soil map & Polygon & $1: 50000$ & $\begin{array}{l}\begin{array}{l}\text { Bureau of Soils } \\
\text { and } \\
\text { Management }\end{array} \\
\end{array}$ \\
\hline $\begin{array}{l}\text { Other } \\
\text { factor } \\
\text { maps }\end{array}$ & $\begin{array}{l}\text { Grid and } \\
\text { Polygon- } \\
\text { Grid }\end{array}$ & $\begin{array}{l}2 \mathrm{~m} \times 2 \mathrm{~m} \\
\text { and } 30 \mathrm{~m} \\
\times 30 \mathrm{~m}\end{array}$ & $\begin{array}{l}\text { WV2 image and } \\
\text { Landsat } 5\end{array}$ \\
\hline
\end{tabular}

Table 1. Spatial data layers used in this study

Six landslide conditioning factors were derived from the DEM using ArcMap Spatial Analyst: elevation, slope angle, slope aspect, plan curvature, profile curvature and distance to drainage. Three factors were derived from scanned maps: (1) lithology, (2) soil type, and (3) distance to fault/ lineament. From the HRSI, three factors were derived: (1) land use/ land cover (LULC) (HRSI data was complemented by Landsat data prior to landslide event), (2) distance to road, and (3) NDVI.

The Kolmogorov-Smirnov (K-S) test for normality was applied to each of the factors using SPSS v.22. For reclassification purposes, Akgun et al. (2012) recommended using either the equal interval or standard deviation classifier when data are normally distributed and either the quantile or natural breaks method when data distribution is skewed. The reclassification of variables was then achieved based on the distribution type, expert knowledge and field observations. All requisite calculations were performed in ArcMap v.10.2. All factors were converted to a raster grid of $10 \mathrm{~m} \mathrm{x} 10 \mathrm{~m}$ cells.

\subsection{Computation of frequency ratio}

In the FR approach, the goal is to reveal the correlation between landslide locations and the factors in the study area. Each thematic map is thus matched with the landslide training data to obtain the FR. The FR is computed from the ratio of landslide occurrence percentage to area coverage percentage for a given factor class, or simply the landslide occurrence area to the total area (Angillieri, 2015; Hong et al., 2015; Meten et al., 2015; Ramesh and Anbazhagan, 2015; Regmi et al., 2014). The values obtained represent the correlation between each factor class and landslide probability. If the FR ratio is greater than 1, then the 
relationship between landslide occurrence and the factor class is strong. If the ratio is less than 1 , then it is regarded as weak.

The frequency ratio of each factor class $\mathrm{i}(\mathrm{FR}$ i) was then computed as:

$$
F R i=\frac{\text { landslide occurrence percentage }}{\text { area occurrence percentage }}=\frac{\frac{N p i x\left(S_{i}\right)}{\sum N p i x\left(S_{i}\right)}}{\frac{N p L\left(N_{i}\right)}{\sum N p i x\left(N_{i}\right)}}
$$

where $\operatorname{Npix}\left(S_{i}\right)$ is the number of cells with landslides in factor class i

$\Sigma$ Npix (Si) is the total number of cells with landslides

$\operatorname{Npix}\left(N_{i}\right)$ is the total number of cells (i.e., with and without landslides) in factor class $\mathrm{i}$

$\Sigma$ Npix (Ni) is the total number of cells (i.e., with and without landslides)

The frequency ratio computations were undertaken in Excel. The landslide susceptibility index (LSI) is then computed as

$\mathrm{LSI}=\sum_{1}^{n} F R j(\mathrm{j}=1$ to $\mathrm{n}), \mathrm{n}$ is total number of factors (Eq. 3).

Higher LSI values imply greater tendencies for landsliding. The data distribution was examined prior to the classification of LSI values into five categories of landslide susceptibility (very low, low, moderate, high, very high). With SPSS v.22, the Kolmogorov-Smirnov test was applied to test for normality. The choice of classifier was guided by the findings of Akgun et al. (2012). The classifier that showed better model sufficiency was selected.

\subsection{Model evaluation}

One measure of model sufficiency is obtained by estimating the number of landslide cells within various classes of susceptibility. Acceptable model sufficiency is observed when the number of landslide cells is nil or low in the low classes, increases from low to high classes, and is highest in the highend classes (Tsangaratos et al., 2016). In addition, the landslide susceptibility map was verified by comparing the susceptibility map with training data that were used for building the models and then with the validation data. The purpose was to evaluate the fitness and predictability of the model based on the training and validation data, respectively. The method required the construction of a specific rate curve that explains the percentage of known landslides that fall into each defined level of LSI values and displays as a cumulative frequency diagram. The LSI values in the FR model were arranged in descending order. The ordered cell values were then divided into 100 equal interval classes. The lower LSI limit values for each $1 \%$-interval class were then recorded. The LSI values for each cell in the training and validation data sets were also arranged in descending order. The cumulative frequency of the LSI values above each of the recorded class limits was then calculated. The areas under the curve (AUC) of the rate curves were then calculated in Excel using the trapezoid method (Choi et al., 2012; Chung and Fabbri, 2003; Intarawichian and Dasananda, 2011; Lee and Pradhan , 2007). The results were converted to percentages to obtain success and prediction accuracy or rates (SR and PR, respectively).
The workflow for undertaking LSA is summarized in Figure 2.

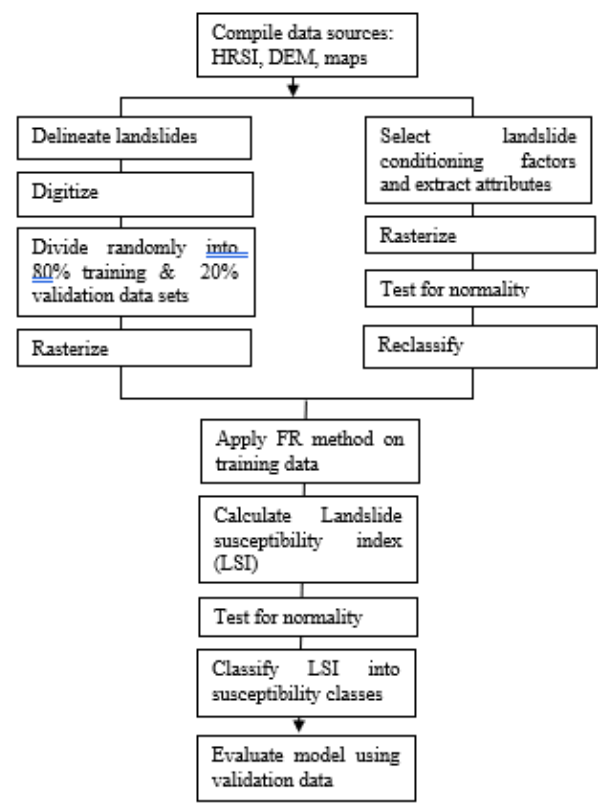

Figure 2. General work flow for landslide susceptibility assessment using frequency ratio

\section{RESULTS}

\subsection{Delineated landslides}

Initially, 853 landslides were delineated. The smallest and largest in size were 20 and $70,215 \mathrm{~m}^{2}$, respectively. Most were of the slide and debris flow types. Selecting the large landslides, i.e., those with areas of more than 900 square meters, 305 landslides were retained for modelling and validation. These landslides covered $2.8 \%$ of the $40.5 \mathrm{~km}^{2}$ study area. For training and validation data sets, 244 landslides $(80 \%)$ and 61 landslides $(20 \%)$ were used, respectively. Training data included 8713 cells and validation data included 2713 cells (Figure 3). Non-landslide cells totalled 393,169.

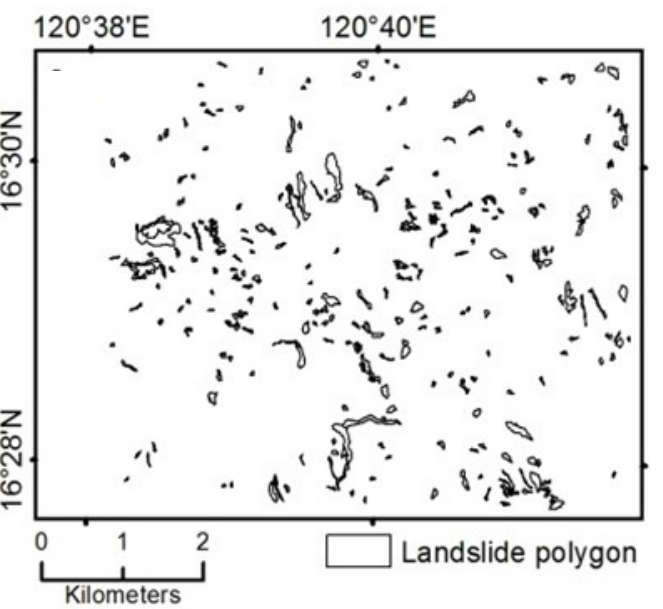

Figure 3. Three hundred five landslides (with area $>900 \mathrm{~m}^{2}$ ) used in modelling landslide susceptibility

\subsection{Landslide conditioning factors and frequency ratio}

Based on the K-S test, the distribution of the twelve landslide conditioning factors showed significant difference $(p<0.05)$ 
from normality. The factors with continuous values were thus. reclassified using the natural breaks method. The results of the FR method are summarized in Table $2 \mathrm{a}-2 \mathrm{~b}$.

\begin{tabular}{|c|c|c|c|c|c|}
\hline $\begin{array}{l}\text { Factors and factor } \\
\text { classes }\end{array}$ & $\begin{array}{l}\text { Number } \\
\text { of } \\
\text { pixels } \\
\text { in class }\end{array}$ & $\begin{array}{l}\text { Number } \\
\text { of pixels } \\
\text { with } \\
\text { landslides }\end{array}$ & \multicolumn{2}{|c|}{$\begin{array}{ll}\text { Class } & \text { Landslide } \\
\text { area } & \text { area } \\
\text { coverage } & \text { coverage }\end{array}$} & FR \\
\hline \multicolumn{6}{|c|}{$\begin{array}{l}\text { Elevation (meters } \\
\text { above sea level) }\end{array}$} \\
\hline $800-1000$ & 336 & 0 & 0.08 & 0.00 & 0.00 \\
\hline $1000-1200$ & 68811 & 1151 & 17.01 & 15.77 & 0.93 \\
\hline $1200-1400$ & 144847 & 2027 & 35.80 & 27.77 & 0.78 \\
\hline $1400-1600$ & 116292 & 3089 & 28.74 & 42.32 & 1.47 \\
\hline $1600-1800$ & 73328 & 980 & 18.12 & 13.43 & 0.74 \\
\hline $1800-2000$ & 981 & 52 & 0.24 & 0.71 & 2.94 \\
\hline \multicolumn{6}{|l|}{ Slope (degree) } \\
\hline $0-10$ & 32707 & 195 & 8.08 & 2.67 & 0.33 \\
\hline-20 & 123379 & 1840 & 30.49 & 25.21 & 0.83 \\
\hline $20-30$ & 164446 & 3573 & 40.64 & 48.95 & 1.20 \\
\hline $30-40$ & 75832 & 1510 & 18.74 & 20.69 & 1.10 \\
\hline-50 & 8025 & 179 & 1.98 & 2.45 & 1.24 \\
\hline $50-60$ & 206 & 2 & 0.05 & 0.03 & 0.54 \\
\hline \multicolumn{6}{|l|}{ Aspect } \\
\hline Flat & 168 & 0 & 0.04 & 0.00 & 0.00 \\
\hline North & 36937 & 268 & 9.13 & 3.67 & 0.40 \\
\hline Northeast & 34677 & 269 & 8.57 & 3.69 & 0.43 \\
\hline East & 44123 & 980 & 10.91 & 13.43 & 1.23 \\
\hline Southeast & 64046 & 2006 & 15.83 & 27.48 & 1.74 \\
\hline Sout & 60760 & 1631 & 15.02 & 22.35 & 1.49 \\
\hline Southwest & 50081 & 992 & 12.38 & 13.59 & 1.10 \\
\hline West & 64089 & 910 & 15.84 & 12.47 & 0.79 \\
\hline Northwest & 49714 & 243 & 12.29 & 3.33 & 0.27 \\
\hline \multicolumn{6}{|l|}{ Plan curvature } \\
\hline Sideward concave & 178111 & 3680 & 44.02 & 50.42 & 1.15 \\
\hline Linear & 43794 & 694 & 10.82 & 9.51 & 0.88 \\
\hline Sideward convex & 182690 & 2925 & 45.15 & 40.07 & 0.89 \\
\hline \multicolumn{6}{|l|}{ Profile curvature } \\
\hline Upward convex & 190967 & 3312 & 47.20 & 45.38 & 0.96 \\
\hline Linear & 28623 & 443 & 7.07 & 6.07 & 0.86 \\
\hline Upward concave & 185005 & 3544 & 45.73 & 48.55 & 1.06 \\
\hline \multicolumn{6}{|l|}{$\begin{array}{l}\text { Distance to } \\
\text { drainage (meter) }\end{array}$} \\
\hline $0-100$ & 90173 & 2000 & 22.29 & 27.40 & 1.23 \\
\hline $100-200$ & 83610 & 1457 & 20.67 & 19.96 & 0.97 \\
\hline $200-300$ & 78958 & 1093 & 19.52 & 14.97 & 0.77 \\
\hline $300-400$ & 65929 & 1114 & 16.30 & 15.26 & 0.94 \\
\hline $400-500$ & 47162 & 891 & 11.66 & 12.21 & 1.05 \\
\hline$>500$ & 38763 & 744 & 9.58 & 10.19 & 1.06 \\
\hline \multicolumn{6}{|l|}{ Soil } \\
\hline $\begin{array}{l}\text { Rough } \\
\text { mountainous land } \\
\text { Ambassador silt }\end{array}$ & 21148 & 90 & 5.23 & 1.23 & 0.24 \\
\hline loam & 304293 & 6966 & 75.21 & 95.44 & 1.27 \\
\hline $\begin{array}{l}\text { Puguis gravelly } \\
\text { loam } \\
\text { Halsema clay }\end{array}$ & 39269 & 67 & 9.71 & 0.92 & 0.09 \\
\hline loam & 39885 & 176 & 9.86 & 2.41 & 0.24 \\
\hline
\end{tabular}

Table 2a. Landslide conditioning factors, factor class and frequency ratio (FR). High FR (>1.2) in bold

\begin{tabular}{|c|c|c|c|c|c|}
\hline $\begin{array}{l}\text { Factors and factor } 1 \\
\text { classes }\end{array}$ & $\begin{array}{l}\text { Number } \\
\text { of } \\
\text { pixels } \\
\text { in class } 1\end{array}$ & $\begin{array}{l}\text { Number } \\
\text { of pixels } \\
\text { with } \\
\text { landslides }\end{array}$ & $\begin{array}{l}\text { Class } \\
\text { area } \\
\text { coverage } \\
\%\end{array}$ & $\begin{array}{l}\text { Landslide } \\
\text { area } \\
\text { coverage } \\
\%\end{array}$ & FR \\
\hline \multicolumn{6}{|l|}{ Lithology } \\
\hline Balatoc dacite & 4748 & 17 & 1.17 & 0.23 & 0.20 \\
\hline $\begin{array}{l}\text { Black Mountain } \\
\text { quartz diorite } \\
\text { Central Cordillera }\end{array}$ & 49108 & 1093 & 12.14 & 14.97 & 1.23 \\
\hline Diorite Complex & 128740 & 2412 & 31.82 & 33.05 & 1.04 \\
\hline Zigzag Formation & 53756 & 46 & 13.29 & 0.63 & 0.05 \\
\hline Pugo Formation & 168243 & 3731 & 41.58 & 51.12 & 1.23 \\
\hline \multicolumn{6}{|l|}{$\begin{array}{l}\text { Distance to } \\
\text { lineament (meter) }\end{array}$} \\
\hline $0-100$ & 54779 & 1290 & 13.54 & 17.67 & 1.31 \\
\hline $100-2$ & 51700 & 1385 & 12.78 & 18.98 & 1.48 \\
\hline $200-300$ & 49866 & 933 & 12.32 & 12.78 & 1.04 \\
\hline $300-4$ & 47344 & 735 & 11.70 & 10.07 & 0.86 \\
\hline $400-50$ & 43357 & 722 & 10.72 & 9.89 & 0.92 \\
\hline$>500$ & 157549 & 2234 & 38.94 & 30.61 & 0.79 \\
\hline \multicolumn{6}{|l|}{ Land use/cover } \\
\hline Dense vegetation & 127907 & 3098 & 31.61 & 42.44 & 1.34 \\
\hline Bare g & 24118 & 344 & 5.96 & 4.71 & 0.79 \\
\hline Sparse vegetation & 215393 & 3793 & 53.24 & 51.97 & 0.98 \\
\hline Drainage & 16268 & 0 & 4.02 & 0.00 & 0.00 \\
\hline House/building & 9958 & 0 & 2.46 & 0.00 & 0.00 \\
\hline Road & 7434 & 64 & 1.84 & 0.88 & 0.48 \\
\hline Mine or quarry & 3517 & 0 & 0.87 & 0.00 & 0.00 \\
\hline \multicolumn{6}{|l|}{$\begin{array}{l}\text { Distance to road } \\
\text { (meter) }\end{array}$} \\
\hline $0-100$ & 103050 & 1406 & 25.47 & 19.26 & 0.76 \\
\hline $100-200$ & 73746 & 1406 & 18.23 & 19.26 & 1.06 \\
\hline $200-300$ & 58278 & 1019 & 14.40 & 13.96 & 0.97 \\
\hline $300-400$ & 43776 & 771 & 10.82 & 10.56 & 0.98 \\
\hline $400-500$ & 31893 & 616 & 7.88 & 8.44 & 1.07 \\
\hline$>500$ & 93852 & 2081 & 23.20 & 28.51 & 1.23 \\
\hline \multicolumn{6}{|l|}{ NDVI } \\
\hline$-0.210-0.227$ & 24707 & 371 & 6.11 & 50.84 & 8.33 \\
\hline $0.227-0.377$ & 25853 & 1902 & 6.39 & 26.06 & 4.08 \\
\hline $0.377-0.503$ & 50764 & 758 & 12.55 & 10.38 & 0.83 \\
\hline $0.503-0.607$ & 82798 & 498 & 20.46 & 6.82 & 0.33 \\
\hline $0.607-0.696$ & 130538 & 308 & 32.26 & 4.22 & 0.13 \\
\hline $0.696-0.996$ & 89935 & 122 & 22.23 & 1.67 & 0.08 \\
\hline
\end{tabular}

Table 2b. Landslide conditioning factors, factor class and frequency ratio (FR). High FR $(>1.2)$ in bold

\subsection{Landslide susceptibility}

Following Akgun et al. (2012b), the natural breaks and quantile classification methods were applied on the landslide susceptibility indices obtained.. Since the quantile classifier showed better model sufficiency, it was chosen as the classifier for LSI. In the resulting model, the high and very high susceptibility classes covered $40 \%$ of the area. The moderate, low and very low susceptibility classes accounted for $20 \%$ each. The landslide susceptibility model is shown in Figure 3.

There appears a prominent band of low and very low landslide susceptibility areas in the west. To the east of this band are moderate to very high-susceptibility areas covering approximately two-thirds of the area. The high-susceptibility areas are interrupted by low-susceptibility corridors coincident with ridges or roads. 


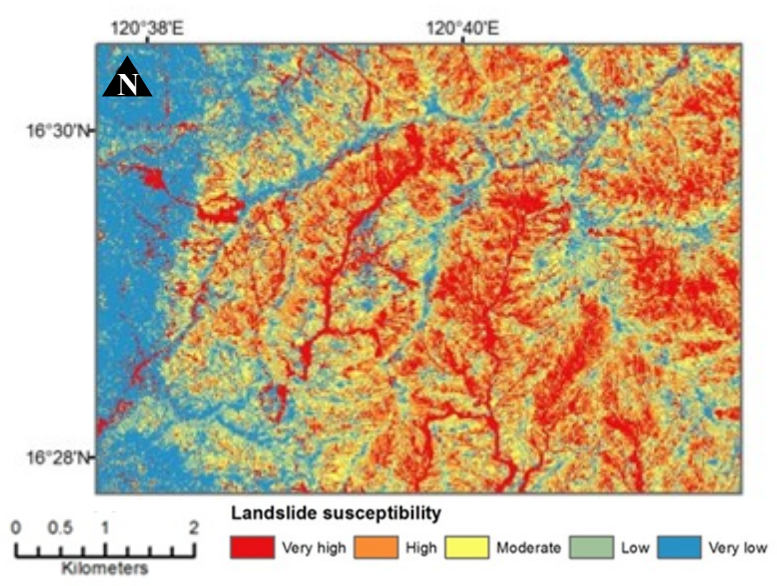

Figure 4. Landslide susceptibility map for southern Tublay, Benguet province

\subsection{Model Sufficiency}

Using all factor sets, the very high, high, moderate, low and very low classes included an average of $86 \%, 7 \%, 4 \%, 3 \%$ and $1 \%$ of the training cells, and $84 \%, 7 \%, 5 \%, 3 \%$ and $1 \%$ of the validation cells, respectively (Figure 5).

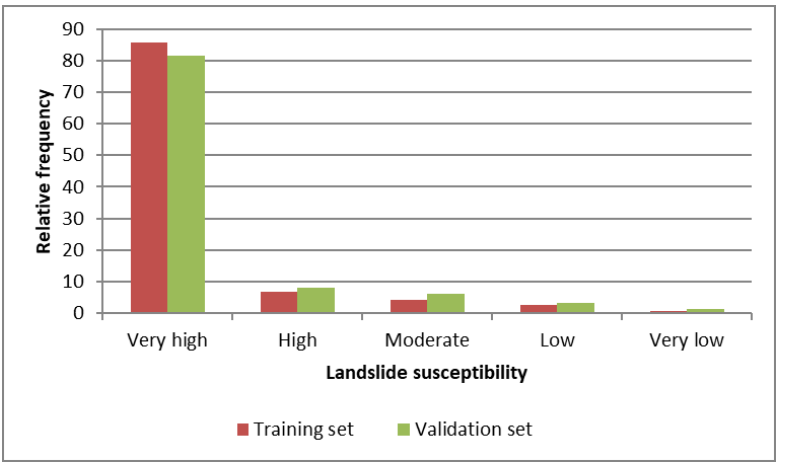

Figure 5. Histograms showing distribution of training (red) and validation (green) data in landslide susceptibility classes

The landslide susceptibility model indicates that $10 \%(100 \%$ $90 \%$ classes) and $20 \%(100 \%-80 \%$ classes $)$ of the most susceptible in the area contain an average of $76 \%$ and $86 \%$, respectively, of the training data (Figure 6). The model can thus be regarded as a good fit to the training data. Moreover, the model indicates that $10 \%$ and $20 \%$ of the most susceptible areas contain $73 \%$ and $82 \%$, respectively, of the validation data set. The predictive value of the model can thus be regarded as good. The SR and PR average $90 \%$ and $89 \%$, respectively.

\section{DISCUSSION}

The use of the criterion NDVI $<0.3$ and band ratios proved useful in identifying candidate landslides. There was general agreement between the candidate landslides identified from HRSI and field observations. Results from image processing complemented with fieldwork data facilitated the process of building the landslide inventory.

For the study site, higher FR $(>1.2)$, which correlates with higher landslide occurrence, are observed in the following factor classes: NDVI is below 0.38 , elevation is $1400-1600 \mathrm{~m}$ and 1800-2000 m, slope is 20-30 degrees and 40-50 degrees, aspect is east, southeast and south, distance to drainage is $0-100$ $\mathrm{m}$, soil is Ambassador silt loam, lithology is Black Mountain quartz diorite porphyry and Pugo Formation, distance to fault/lineament is $<200 \mathrm{~m}$, distance to road is $>500 \mathrm{~m}$, LULC is dense vegetation. The five most influential factor classes (i.e. with highest FR) were NDVI $<0.38$, elevation is $1800-2000 \mathrm{~m}$, aspect is southeast, dense vegetation and distance to lineament is $<200 \mathrm{~m}$. . The high FR values coincide with steeper slopes, drainages and gullies, vegetated and bare surface, and highly weathered soil and rocks. Except for the occurrence of dense vegetation, most of the stated conditions are known to promote slope instability by increasing shear stresses and/or reducing shear strength (Crozier, 1986; Petley, 2010). That landslides tended to occur in the south- and southeast-facing slopes which are the predominant slope directions - may be the effect of the near north-south oriented morphology of the mineralized catchments and the general southward flow direction of stream flow. Based on Table 2a above, the plan and profile curvature factors did not appear to have influence on slope instability.

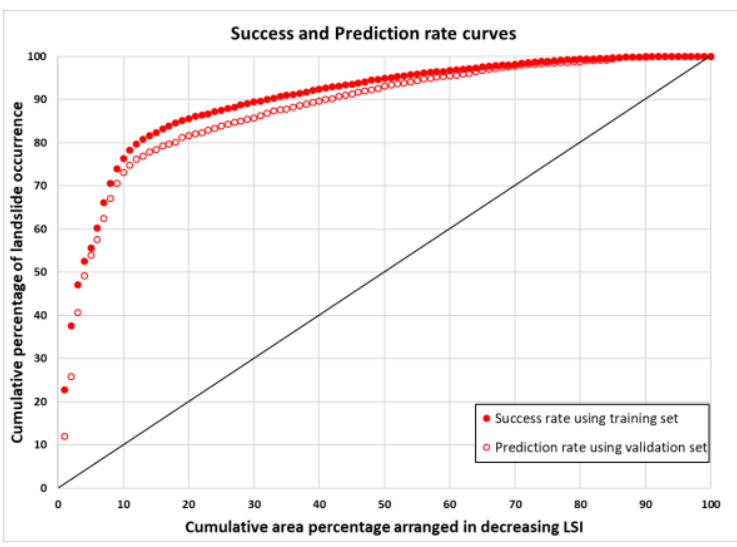

Figure 6. Success (filled circle) and Prediction rates (open circle) of frequency ratio model using twelve landslide conditioning factors derived from DEM, map and highresolution satellite imagery

Among the map factors, the high FR values for the Ambassador silt loam and Black Mountain quartz diorite porphyry and Pugo Formation lithology classes are consistent with field observations. The higher FR in areas closer to lineaments/ faults $(<200 \mathrm{~m})$ supports the general tendency of landslides to occur closer to fractures.

Among the LULC classes, the highest FR (1.3) is observed in the dense vegetation class. This is contrary to expectation because root systems of vegetation hold regolith, generally promoting slope stability (Wu and Swanston, 1980). However, along slopes, vegetation can slow runoff allowing more water to infiltrate into the subsurface, saturating the soil quicker and to greater depths. Moreover, it is also possible that during and immediately after a high rainfall event, the added weight of water-saturated regolith and vegetation elevates shear stresses and instigates instability. In the field site, the dense vegetation areas are located in midslopes subjacent to drainage divides, agricultural lands, roads, mines and quarries. It is from the latter locations at higher elevation that landslides may originate and gain momentum to cascade down to vegetated ground downslope. It is also possible that in areas classified as having dense vegetation, some bare or sparsely vegetated ground is present, and it is from the latter where landslides initially trigger and eventually destabilize the adjacent vegetated areas. Greater 
landslide occurrence may thus be observed in the dense vegetation class. The low FR (0.98) observed in the sparse vegetation class seems to imply a lesser landslide occurrence. It is possible that because only larger landslides were included in the training set, the omission of smaller landslides likely resulted in a more conservative number of landslides, thus reducing the FR. For the distance to road factor, a possible reason why the 0-200 meter classes showed low FR could be attributed to the regular slope reduction/ maintenance work or the presence of slope protection infrastructure including grouted slopes, culverts, retaining walls, drainage canals and the like. Among all factors, the highest FR (8.3 and 4.1) observed in the lowest NDVI classes $(<0.38)$ indicate that low NDVI is most strongly associated with landslide occurrence. The low NDVI is observed not only in landslide areas but also in main river drainage, floodplains, built-up areas, mines and quarries. While it is possible that landslide material from upslope can accumulate in river drainage and floodplain, it is possible that such deposits are worked by normal river flow, especially during the waning stages of high discharge. One evident limitation of the models apparently is the inclusion of river drainages and floodplains (consisting mostly of sand and gravel) in the high and very high susceptibility zones (Figure 4). Because the model is strongly affected by NDVI, the low NDVI of these two features are similar to the low NDVI signatures of "true" landslides. How to better discriminate them could be a topic for further study.

\section{CONCLUSION}

The results confirm that the FR method applied on the twelve factors can adequately model the landslide susceptibility in the area. Applying quantile classification of LSI values, the number of training and validation landslides is lower in lowsusceptibility areas, increases with increasing susceptibility classes, and is highest (more than 80\%) in the high and very high categories.

The generated landslide susceptibility model can be regarded as sound and suitable for guiding decisions pertinent to landslide hazard mitigation at the municipality level. The methodology adopted here is expeditious, straightforward, evidence-based and cost-effective for local planning purposes. It provides a sound estimate of the landslide susceptibility and hence can be readily replicated in similar landslide prone areas.

\section{ACKNOWLEDGEMENTS}

This research was supported by the Department of Physical Science, College of Science and the Cordillera Studies Center of the University of the Philippines Baguio. The authors are thankful for the constructive comments of Prof. JP Mendoza of UP Baguio. The authors are grateful to the support extended by the local government unit of the municipality of Tublay.

\section{REFERENCES}

Akgun, A., Kincal, C., \& Pradhan, B. (2012). Application of remote sensing data and GIS for landslide risk assessment as an environmental threat to Izmir city (west Turkey). Environmental Monitoring and Assessment, 184(9), 5453-5470.

Akgun, A., Sezer, E. A., Nefeslioglu, H. A., Gokceoglu, C., \& Pradhan, B. (2012). An easy-to-use MATLAB program (MamLand) for the assessment of landslide susceptibility using a Mamdani fuzzy algorithm. Computers \& Geosciences, 38(1), 23-34.
Aleotti, P., \& Chowdhury, R. (1999). Landslide hazard assessment: summary review and new perspectives. Bulletin of Engineering Geology and the Environment, 58(1), 21-44.

Angillieri, M. Y. (2015). Application of logistic regression and frequency ratio in the spatial distribution of debrisrockslides: Precordillera of San Juan, Argentina. Quaternary International, 355, 202-208. doi:10.1016/j.quaint.2014.11.002

Choi, J., Oh, H.-J., Lee, H.-J., Lee, C., \& Lee, S. (2012). Combining landslide susceptibility maps obtained from frequency ratio, logistic regression, and artificial neural network models using ASTER images and GIS. Engineering Geology, 124, 12-23.

Chung, C.-J. F., \& Fabbri, A. G. (2003). Validation of spatial prediction models for landslide hazard mapping. Natural Hazards, 30(3), 451-472.

Cinco, T. A., Guzman, R. G., Ortiz, A. M. D., Delfino, R. J. P., Lasco, R. D., Hilario, F. D., . . Ares, E. D. (2016). Observed trends and impacts of tropical cyclones in the Philippines. International Journal of Climatology.

Crozier, M. J. (1986). Landslides: causes, consequences and environment: Croom Helm London etc.

Forbes, K., \& Broadhead, J. (2011). Forests and Landslides. Retrieved from http://www.fao.org/docrep/016/ba0126e/ba0126e00.p df

Greenbaum, D. (1995). Project summary report: Rapid methods of landslide hazard mapping. In Overseas Geology Series: British Geological Survey (BGS).

Hong, H., Xu, C., \& Bui, D. T. (2015). Landslide Susceptibility Assessment at the Xiushui Area (China) Using Frequency Ratio Model. Procedia Earth and Planetary Science, 15, 513-517.

Kirschbaum, D., Stanley, T., \& Zhou, Y. (2015). Spatial and temporal analysis of a global landslide catalog. Geomorphology, 249, 4-15.

Kjekstad, O., \& Highland, L. (2009). Economic and social impacts of landslides. In Landslides-Disaster Risk Reduction (pp. 573-587): Springer.

Lee, S., \& Pradhan, B. (2007). Landslide hazard mapping at Selangor, Malaysia using frequency ratio and logistic regression models. Landslides, 4(1), 33-41.

Magliulo, P., Di Lisio, A., \& Russo, F. (2009). Comparison of GIS-based methodologies for the landslide susceptibility assessment. Geoinformatica, 13(3), 253265.

Meten, M., Bhandary, N. P., \& Yatabe, R. (2015). GIS-based frequency ratio and logistic regression modelling for landslide susceptibility mapping of Debre Sina area in central Ethiopia. Journal of Mountain Science, 12(6), 1355-1372.

Metternicht, G., Hurni, L., \& Gogu, R. (2005). Remote sensing of landslides: An analysis of the potential contribution to geo-spatial systems for hazard assessment in mountainous environments. Remote sensing of Environment, 98(2), 284-303.

Nolasco-Javier, D., Kumar, L., \& Tengonciang, A. M. P. (2015). Rapid appraisal of rainfall threshold and selected landslides in Baguio, Philippines. Natural Hazards, 78(3), 1587-1607.

Petley, D. (2010). On the impact of climate change and population growth on the occurrence of fatal landslides in South, East and SE Asia. Quarterly Journal of Engineering Geology and Hydrogeology, 43(4), 487-496. 
Petley, D. (2012). Global patterns of loss of life from landslides. Geology, 40(10), 927-930.

Pradhan, B. (2010). Landslide susceptibility mapping of a catchment area using frequency ratio, fuzzy logic and multivariate logistic regression approaches. Journal of the Indian Society of Remote Sensing, 38(2), 301320.

Ramesh, V., \& Anbazhagan, S. (2015). Landslide susceptibility mapping along Kolli hills Ghat road section (India) using frequency ratio, relative effect and fuzzy logic models. Environmental Earth Sciences, 73(12), 80098021. doi:10.1007/s12665-014-3954-6

Regmi, A., Devkota, K., Yoshida, K., Pradhan, B., Pourghasemi, H., Kumamoto, T., \& Akgun, A. (2014). Application of frequency ratio, statistical index, and weights-of-evidence models and their comparison in landslide susceptibility mapping in Central Nepal Himalaya. Arabian Journal of Geosciences, 7(2), 725-742. doi:10.1007/s12517-0120807-Z

Tsangaratos, P., \& Ilia, I. (2016). Comparison of a logistic regression and Naïve Bayes classifier in landslide susceptibility assessments: The influence of models complexity and training dataset size. Catena, 145, 164-179. doi:http://dx.doi.org/10.1016/j.catena.2016.06.004

Van Westen, C. J., Castellanos, E., \& Kuriakose, S. L. (2008). Spatial data for landslide susceptibility, hazard, and vulnerability assessment: an overview. Engineering Geology, 102(3), 112-131.

Yumul, G. P., Cruz, N. A., Servando, N. T., \& Dimalanta, C. B. (2011). Extreme weather events and related disasters in the Philippines, 2004-08: a sign of what climate change will mean? Disasters, 35(2), 362-382. 